\title{
Love in Robert Browning's Poems
}

\author{
Chunhong Yang \\ North China Electric Power University
}

\begin{abstract}
Robert Browning is considered as an optimist, but in his love poems run a torrent of devastation and destruction. Both in his poetry of courtship and poetry of marriage, there are damaging and harrowing love experiences. "Porphyria's Lover" and "My Last Duchess" are typical examples. Both dramatic personae, motivated by their extreme desire of dominance, murder their beloved ones. Therefore, in Browning's world of love, the relationships are blighted by loss and disillusion.
\end{abstract}

\author{
Ah, love let us be true \\ To one another! For the world which seems \\ To lie before us like a land of dreams, \\ So various, so beautiful, so new, \\ Hath really neither joy, nor love, nor light, \\ Nor certitude, nor peace, nor help for pain. (Il. 29-34)
}

cried Arnold in "Dover Beach", and to modern readers the cry might seem desperate and poignantly ineffectual, but for Arnold and his contemporaries this egoism was a force in which one could repose faith. "Victorian love poetry, on the whole, attests to the strength and resilience of the love relationship, and takes it as a major theme" (Richards 119). Many Victorian poets continued the tradition that love ennobles and leads men and women into highest and most praiseworthy states; or love is a powerful, life-enhancing force that inspired belief; or as "Dover Beach" suggests, love is a refuge from a hostile and unpleasant world. Much Victorian love poetry dealt with the positive aspects of relationships, but some of the most powerful work treated relationships blighted by loss and disillusion. Browning looms large as the celebrant of damaging and harrowing love experiences; this is somewhat surprising, since he has the reputation of being an optimist. For instance, William DeVane, one of the most influential critics of Browning, acknowledged his "robust and optimistic spirit" (88) .This paper will focus on Browning's problematic and questioning treatments of the subject, and the key case studies here are "Porphyria's Lover" and "My Last Duchess".

To Browning, love was also a great force in one's life. The beginning poem in Men and Women"Love among the Ruins" illustrates his great faith in love. It is set in a fair outdoors country dotted with ruins dating from pre-Roman antiquity. The young speaker walks through "solitary pastures" (3) ${ }^{1}$ which were "the site once of a city of great and gay,/...Of our country's very capital" (7-9). But the speaker's interest is actually "a girl with eager eyes and yellow hair" (55) whom he is to find in the "single little turret"(37) which is all that remains of a lofty structure upon which the amphitheater, the city, and the empire have centered:

${ }^{1}$ All Browning's poems anthologized in this paper are taken from Robert Browning's Poetry: A Norton Critical Edition, 2007. 
Oh heart! Oh blood that freezes, blood that burns,

Earth's returns

For whole centuries of folly, noise, and sin!

Shut them in

With their triumphs and their glories and the rest.

Love is best! (1l. 79-84)

Here, the "center" of the city-the "single little turret", which contains the love of the speaker-symbolizes love, the central force in the world. So Browning placed this poem at the very beginning of Men and Women with the clear intention of establishing a high, youthful, positive note at the beginning. However, it is only his "intention" to portray a positive picture on love. In his later poems, he was perceptive enough to register timidity, inadequacy, and other failings in love relationships, though love was a great central value for him- perhaps that was why he took shortcomings in its pursuit so seriously.

\section{POETRY OF COURTSHIP}

"The Statue and The Bust" is a key document in the study of courtship. It is the story of the Duke of Florence's illicit love for a bride of Riccardi. They meet and exchange knowledge of love in a split second. The husband, suspecting his wife, locks her up. The lovers delay elopement, and when the woman is aware of ageing, she orders Della Robbia to make a statue of her, to place in the window where she was accustomed to looking out for the Duke. Since she has not been animated by divine commitment the "the lady of clay" (186) is an adequate substitute. The Duke likewise is aware that his youth is going and his "dream escapes"(197); he commissions John of Douai to fashion a bronze statue to capture the love of life he once had but has now lost. Both lovers are content with external images of themselves, which arrest their love at a certain point. Strictly speaking, the images do not tell the whole truth either, since they do not capture the timidity and idleness. They fail the test of life, and the speaker says that a crime is just as effective a judge "as virtue golden through and through" (229). The sin he imputes "to each frustrate ghost \Is -the unlit lamp and the ungirt loin" (247).

"The Statue and the Bust" creates a good example of the timidity and inadequacy in courtship. However, Browning's key interests when depicting love lay in the damaging aspect of love. He produced a great amount of poetry dealing with infidelity, murder, etc. For instance, "In a Gondola" is a tale of murder caused by female infidelity. It takes the form of a lyric dialogue between two lovers at the end of a tryst, which is imbued with sexuality and Venetian local color. The lady's husband, one of a grisly clan called "the Three" (208), acts rather than speaks; and, as the love-freighted gondola touches its jetty, her lover is "surprised and stabbed" (224). "The Laboratory" treats similar themes, and the difference is that this time it is a girl instead of a man who would take actions. A young girl frustrated in love sits watching an old apothecary mix her a "delicate droplet" (43) of poison. Her intended victim is a magnificent "she" who is even then trysting with the man the girl professes to love. Our speaker lusts to give pain as well as death: "Brand, burn up, bite into.../...her dying face" (39-40). Whether or not her megalomania bears fruit we are not told, but we have been told clearly that she is mad, and how, and why.

Comparatively speaking, the two poems mentioned above are easier for readers to comprehend because in them the murderers try to kill the persons who are on their way of love, or who own their beloved ones. Among the portrayal of Browning's troubled relationship between men and women, the most striking depictions are those characters who kill their own beloved ones. 
A much more macabre arresting of a moment of love at a certain point is "Porphyria's Lover". At the instant when Porphyria surrenders herself to her lover he kills her. Why does he kill Porphyria? Some critics search the causes within the vampire lore. For instance, Michael L. Burduck, justifies the man's killing by pointing to Porphyria as a vampire. "The narrator actually believes that The Creator refuses to punish him because he has saved his own soul, as well as Porphyria's, by dispatching one of hell's voracious minions" (166). But it is the man's extreme desire of dominance that results in the horrible ending.

The two characters in the poem are lovers, but there is obviously a great deal of tension between them, and there is a sense of the speaker's unease at Porphyria's power. She is clearly more in charge: she is superior to him socially; she comes to see him and puts his house in order.

When glided in Porphyria: straight

She shut the cold out and the storm,

And kneeled and made the cheerless grate

Blaze up, and all the cottage warm;

Which done, she rose, and from her form

Withdrew the dripping cloak and shawl,

And laid her soiled gloves by; untied

Her hat and let the damp hair fall,

And, last, she sat down by my side

And called me. (1l. 6-15)

Porphyria enters the speaker's cottage, and immediately the tone of the poem changes. In line 4, the speaker introduces himself as passively listening to what was going on outside, but in his description of Porphyria, he presents a woman who busily and actively moves around. "Her aggressiveness penetrates even the diction" (Walker, 166). In these ten lines, in which Porphyria is depicted, Browning uses an abundance of verbs, which show her as performing no less than twelve actions. However, even as she "shut," "kneeled", "made," "rose," "laid," "untied," etc., there is no sense that she is in a hurry or frenzy. Rather, she is in control of her brusque, purposeful movements, which are emphasized by the use of monosyllables. She enters the cottage and "straight," or right away, gets to work. Her presence shuts out the cold and the storm, again an indication of her strength of personality. Despite the fact that there is a storm raging outside, there is no fire burning, and she sets about making one "blaze up". From this the reader gets a sense of her forcefulness but also of the speaker's passive and depressed state, as he has apparently been sitting alone in his cottage in the middle of a storm without attempting to warm the place up.

Indeed, throughout the poem, there are clear contrast between Porphyria and her lover. She is described in terms of bright color (her yellow hair, the fire she makes blaze up, her blue eyes and rosy face), while he is pale. She is active, he is passive; she is talkative, and he is silent; she comes in after being with many other people, while he sits alone and isolated in his cottage. After she makes the fire, Porphyria rises and takes off her clothes that are wet and soiled from the storm. The poet makes it clear that it is only after she has put the scene in order that she approaches her lover. It is learned that Porphyria unties her hat, lets her hair down, "And, last, sat down by my side." The use of commas around "last" further emphasize that she goes to her lover only after she has set her surroundings right. She then calls to him.

The speaker does not respond to her call after she sits next to him. Interestingly, the speaker does not even present himself as "I", and the sense of his passivity is stressed once more when he says that "no voice replied" to her calls. Porphyria is again the active partner, as she puts her 
arms around the speaker's waist and bares her shoulder to him. She proceeds to seduce him, moving her blonde hair from her shoulder, pressing his cheek against it, and then enfolding him in her long tresses. By modern standards, this description may not be considered sexually explicit, but "in early Victorian poetry this would be considered a daring and erotically charged scene" (Hacht, 153). The fact that the woman dominates and controls the situation is, of course, unusual, and this aspect makes all the more shocking by the fact that she is a married woman.

The speaker seems to resent her power over him. For, while he portrays her as strong and commanding, he insists that she is weak and needs him more than anything else. In lines 31-36, the speaker suddenly uses a series of first-person pronouns: "I looked," "I knew," "my heart," "I debated," "mine, mine," and "I found". He thinks that at "that moment" Porphyria is completely and utterly his, and not only that but she is "fair/Perfectly pure and good". It suddenly occurs to him what he should do, and that thing he finds to do is to take her hair in one "long yellow string" and wind it three times around her throat, strangling her.

When he kills her, he finally reverses their roles so that he is in control; at the end of the poem, she sits with her dead head drooped on his shoulder, when before she had laid his cheeks against hers. The fact that the woman is the more powerful partner in the relationship is contrary to the stereotype, and this may be the reason for the speaker's resentment and anger. The fact that he cannot control her-she has a gay social life that she enjoys-is a likely source of his bitterness, and the only way to rid himself of his feelings of impotence and powerlessness is to kill her.

\section{POETRY OF MARRIAGE}

In Browning's poetry of courtship, he demonstrated the timidity, as shown in "The Statue and the Bust", and life-denying possessiveness, as indicated in "Porphyria's Lover". In his poetry of marriage, he carried on his obsession with the flawed relationship between men and women. Browning's poetry about marriage is a world of quarrel, betrayal, submission and agony.

In "A Woman's Last Word", the speaker is directed against any further words:

Let's contend no more, Love,

Strive nor weep-

All be as before, Love,

-Only sleep. (1l.1-4)

She promises complete submission, and will ("tomorrow/Not tonight") (33-34) meet any demand of his for "flesh or spirit" (31). The man who is the speaker in "A Lover's Quarrel" is more humorous, and brings a wider field of speculation into his discourse. The situation he presents, however, seems much more serious. In early stanzas he reminisces about the good times he has shared with his lover. Every event was then sweet-the morning paper, a book about Argentina, experiments with the occult, and little joking masquerades. That was in winter "three months ago/When we lived blocked up with snow" (15-16). Since then some evil forces have "Pierced to our ingle-glow,/And the friends were fiend and foe!" (82-83) Now the weather is better, but the speaker faces an empty spring and a barren summer. "Andrea del Sarto" is a famous representation of a flawed marriage. It's a poem about the wife's betrayal and assertiveness and the man's debility. Andrea, for the sake of his wife, sacrifices his art for money, while his wife is unfaithful.

As mentioned above, one of the most striking and most horrible element in Browning's love poems is its life-denying possessiveness, as shown in "Porphyria's Lover". In his poems talking about marriage, the one that handles the similar theme with "Porphyria's Lover", is one of the masterpieces of Browning- "My Last Duchess". While Porphyria's lover is from the lower 
classes, the Duke is one of the aristocrats. Though the speakers are from different social status, their motivation to kill the beloved ones is almost the same, which is to obtain their absolute control over the women.

In general, critics have agreed on many basic interpretive issues about "My Last Duchess". William DeVane appeared to voice prevailing opinion when he characterized the last Duchess as an obvious victim-as "outraged innocence" trapped in an age when "no god came to the rescue" (185).

Standing in front of a portrait of the Duchess, the Duke talks about the woman's failings and imperfections. First and foremost, she was innocent, too easily pleased and impressed. He blames her for not seeing any difference between being the wife of a "great man" and being able to see the sunset; receiving a bouquet from someone of status below the Duke's; or riding a white mule. She gave all men the kind of respect that only a man with his family's rank and distinction deserves. Hence, the irony of the poem surfaces as the reader discovers that the young woman's "faults" were qualities like compassion, modesty, humility, delight in simple pleasures, and courtesy to those who served her.

Using abundant details, Browning led the reader to conclude that the Duke finds fault with his former wife because she does not reserve her attentions for him, his rank, and his power. Thus, "Sexual jealousy and fierce, even psychotic possessiveness may well be his fundamental motivation" (Millet, 176). In the poem, the Duke's possessiveness is fully illustrated. The Duke appears more taken with the painting than with the real woman the picture represents. The image of emotion-the "passion" in the "glance" (8)-seems more valuable to him than genuine emotion. In "its earnest glance" (8), the use of the word "its" instead of "her" suggests that the Duke has more of a relationship with the painting than he did with his dead wife. The following lines explain his behavior: "(since none puts by/The curtain I have drawn for you, but I )"(9-10). The Duke cannot control the living woman, while the picture is under his absolute control. So by killing the Duchess he can curb his wife's friendliness and reserve her smiles all for him alone.

The Duke never treats his wife as his equals, but as one of objects in his possession instead. When negotiating the dowry with the envoy, the Duke claims "Though his fair daughter's self, as I avowed/At starting, is my object" (52-53). The word "object" is an important one in making a final and comprehensive assessment of the Duke's character. He is a collector of art objects, after all, and he seems to enjoy showing off his rich collection. After all, the whole occasion of his speech has been an explanation of the origin of a portrait of his former wife. Moreover, on the way out of his art gallery, he takes the time to point out one final art object to his guest: "Notice Neptune, though/Taming a sea-horse, thought a rarity,/Which Claus of Innsbruck cast in bronze for me!" (54-56) Once again the Duke takes the opportunity to show off a piece of art that he is proud of and to drop the name of the artist, hoping to impress his guest. The subject of the sculpture adds to our reaction to the Duke's story; here a powerful god subdues a wild sea-horse, much as the Duke has subdued his former Duchess. And as Neptune tames the sea-horse, he has tamed a former wife, transforming her uncontrollable spirit into an object of art and preserving her loveliness into a medium over which he can exert complete control. The reader should bear in mind the identity of the auditor. The Duke has given all of this information about his personality and the history of his former marriage to an envoy who has been sent to arrange a new marriage. The Duke here is indicating what kind of behavior he will expect in his new wife. Hence, to the Duke, both the former and the would-be Duchess are his objects. 


\section{CONCLUSION}

Browning regarded love as essential in the world, but some of the love poetry he wrote runs a torrent of devastation and destruction. The classic cases are "Porphyria's Lover" and "My Last Duchess". Both speakers, motivated by their extreme desire of dominance, murder their beloved ones. In Robert Browning: Twayne's English Authors Series, "Porphyria'Lover" and "My Last Duchess" were grouped into "Circle of the Violent" (Bowman, 49). Therefore, in Browning's world of love, there are mostly failed loves or love mixed with other moral and ethical problems.

\section{References}

Arnold, Matthew. “Dover Beach”. in The Portable Matthew Arnold. Ed. Lionel Trilling. New York: Penguin, 1980.

Bowman, Sylvia E., ed. Robert Browning: Twayne's English Authors Series. Boston: Twayne, 1974.

DeVane, William C. A Browning Handbook. New York: F. S. Crofts, 1935.

Richards, Bernard. English Poetry of the Victorian Period 1830-1890. London: Longman, 1988. 